\title{
"Historical Processes and the Political Organization of the Hasinai Caddo Indians": A Reply
}

Nancy Adele

Texas Historical Commission

Timothy K. Perttula

Heritage Research Center, Stephen F. Austin State University

Follow this and additional works at: https://scholarworks.sfasu.edu/ita

Part of the American Material Culture Commons, Archaeological Anthropology Commons, Environmental Studies Commons, Other American Studies Commons, Other Arts and Humanities Commons, Other History of Art, Architecture, and Archaeology Commons, and the United States History Commons

Tell us how this article helped you.

This Article is brought to you for free and open access by the Center for Regional Heritage Research at SFA ScholarWorks. It has been accepted for inclusion in Index of Texas Archaeology: Open Access Gray Literature from the Lone Star State by an authorized editor of SFA ScholarWorks. For more information, please contact cdsscholarworks@sfasu.edu. 
"Historical Processes and the Political Organization of the Hasinai Caddo

Indians": A Reply

Creative Commons License

(c) (i) \&

This work is licensed under a Creative Commons Attribution-NonCommercial 4.0 International License 


\title{
"Historical Processes and the Political Organization of the Hasinai Caddo Indians": A Reply
}

\author{
Nancy Adele Kenmotsu and Timothy K. Perttula,
} Texas Historical Commission

In a recent volume of the Caddoan Archeology Newsletter, Daniel Hickerson (1995) argues that Apache aggression across the Southern Plains, Apache trade in horses and other European goods, and European-introduced diseases dramatically affected Caddoan populations by encouraging their migration south to the upper Neches/Angelina river basins area traditionally occupied by one segment of the Caddo, the Hasinai groups. In his opinion (Hickerson 1995:12), the Hasinai confederacy was a nascent chiefdom that developed as a direct result of this midto late-seventeenth century southern migration. As has been pointed out by Caddoan ethnographers, ethnohistorians, and archeologists for 50 years or more, the Caddo were affected by a number of historical processes that resulted from the European exploration and settlement of the New World, and we would agree with Hickerson that these are worthy of study and continual reexamination. How- ever, it is our view that Hickerson's consideration of historical processes has only dealt with a fraction of the available archeological and archival/documentary literature on the Caddo peoples, and this reliance on a limited sample of this material has led to a portrayal of Apache aggression and its effects on the Caddo populations in eastern Texas that is overdrawn and misleading. Furthermore, Hickerson incorrectly characterizes the limitations of the eastern Texas environment, leading to depictions of the region, as an impenetrable forest that stood as a defensive barrier, that do not stand up to scrutiny. Finally, a failure to differentiate between the Caddo and Southern Plains Caddoan-speakers causes Hickerson to inappropriately attribute to the Caddo the effects of Apache hostilities directed against the Pawnee and Wichita, close tribal allies (Meredith 1995:20-21).

\section{Caddoan Coalescence and Apache Aggression}

Hickerson (1995:7) argues that Apache aggression "was a major concern for the Hasinai" and that "violent encounters" between the two groups were increasingly common after $c a$. 1650. The fundamental cause of the increased aggression, according to Hickerson (1995:8), was Apache acquisition of 
large horse herds and Spanish weapons obtained through trade and also through raids on the Spanish and Puebloan settlements in New Mexico. These horses and weapons enabled the Apache to extend their territories to the north and east where they preyed on the Wichita, Pawnee, and, ultimately, the Caddo. It is Hickerson's (1995:8) opinion that, by 1660, the Apaches had "acquired their reputation...as the fearsome and hostile warriors who dominated the southern Plains, a reputation that stayed with them through the eighteenth century". The Caddoan response, says Hickerson (1995:9), was population aggradation in the territory of the Hasinai Caddo between the Neches and Angelina rivers. This region was apparently chosen because it was at some distance from the Apaches and was heavily forested, a condition that Hickerson believes was a barrier to horse travel.

It is our opinion that Hickerson's arguments and conclusions are not well supported by documentary or archeological evidence, although we concur that hostilities did exist between the Caddo and the Apache. For example, the French (Margry n.d., roll 3:348) noted the conflicts with the Apaches in 1687, and, in 1691, Casañas (Swanton 1942:251) listed the Apache as one of the enemies of the Caddo. Hidalgo's (Swanton 1942:269-271) letters offered further support of the enmity between the Apache and the Caddo. Statements of Apache/Caddo hostilities are also present in the writings of Mendoza (AGN 1683),
Lopez (AGN 1684), Paredes (1968:475), Posada (1982:36), Olivares (BA 1719), and others.

There is, however, no archeological or documentary evidence that the level of these hostilities overwhelmed the Caddo or caused their coalescence between the Neches and Angelina rivers. With regard to the archeological data, to date, no sites with abundant evidence of warfare have been identified on the Southern Plains or in eastern Texas. To be sure, only a few historic sites that may be attributable to the Apaches have been identified on the Southern Plains (Spielmann 1982; Habicht-Mauche 1987; Boyd et al. 1994:242; Johnson and Holliday 1995), and the paucity of systematic surveys in the region may account somewhat for the lack of evidence of Apache/Caddoan aggression in that region. More likely, the difficulty in identifying Apache sites is a product of Apache mobility, band structure, and limited time depth in Texas (Black et al. 1996:56). However, that is not true for the eastern Texas Caddo region where archeological investigations for the last $60+$ years for have resulted in surveys of large land masses and in the identification of a wide variety of historic Caddo sites from the Red River to deep eastern Texas (Perttula 1993, 1995). This includes important Caddo sites such as Deshazo (Story 1982, 1995), Mayhew (Kenmotsu 1992), many other Allen phase sites in the Neches and Angelina river drainages (Cole 1975), Kinsloe phase sites on the Sabine 
drainage (Jones 1968), the Goode Hunt and Clements sites near the divide between the Sulphur River and Cypress Bayou (Perttula 1992:188-195), and post1600 Texarkana and McCurtain phase sites along the Red River (Gilmore 1986; Gilmore and McCormick 1980, 1982; Perttula et al. 1995). Although arrowpoints have been recovered in quantity from some of these sites, European weaponry (i.e., gun parts and/or knives) is minimal in an archeological context at any Caddo sites before 1740, and those sites with human remains have no evidence of violent deaths.

In essence, then, the archeological assemblages and settlement/community patterns indicate that these historic Caddo sites were the residences of closely interacting and well-integrated small-scale agriculturists. Moreover, the sites in the Angelina and Neches river basins appear to have been occupied as extended family farmsteads (Kenmotsu 1992) or as small hamlets of several farmsteads (Story 1982, 1995; Cole 1975) that were widely dispersed across the landscape around public buildings used by the tribal leaders. Father Douay in 1687 , for example, commented that the Caddo in the Neches/Angelina river basins lived in a community "at least twenty leagues (about 50 miles, as a league is equivalent to 2.76 miles) long, not continuously settled, but with rancherias of ten or twelve huts" (Hackett 1931-1946, Vol. I, para. 361). We detect no defensive posture in the small, dispersed, late seventeenth century Hasinai communities in eastern Texas.

Contrary to Hickerson's thesis, then, there is no archeological evidence that the Hasinai Caddo communities were occupied by large enclaves of migrant Caddos from regions to the north. Rather, the Caddo rancherias were widely separated from one another by unoccupied lands and hunting territories. Although Hickerson (1995:8) contends that the Apache aggression was sufficient to cause the Caddos and their allies "to concentrate their settlements for the benefit of mutual protection", the archeological record does not support his thesis.

In part, Hickerson's assumption of Apache/Caddo warfare stems from his failure to distinguish between the Caddo, a distinct Native American group occupying the Piney Woods and Post Oak Savannah of eastern Texas, northwestern Louisiana, southwestern Arkansas, and southeastern Oklahoma, and Caddoan speakers, notably the Pawnee and the Wichita. Although the latter share a linguistic base with the Caddo, glottochronologists suggest that, for at least 4000 years, the Caddo language had been evolving separately from the Pawnee or Wichita (Chafe 1990). Ethnological (Swanton 1942) and ethnohistorical (Perttula 1992; Smith 1995) studies support the separation of the Caddo as a distinct cultural and tribal entity from the Pawnee and the Wichita. Because Hickerson lumps Caddoan 
speakers with the Southern Caddo speakers (the affiliated Hasinai, Kadohadacho, and Natchitoches groups), his conclusions regarding hostilities often rest upon documentary evidence related to the Wichita and/or Pawnee, but not to the Caddo.

Spanish and French documents dating from the seventeenth and eighteenth centuries do, as noted above, support the notion of Apache/Caddo hostility. However, our interpretation of the data from those documents differs significantly from the position taken by Hickerson. It is our opinion that the documentary record indicates: 1) that the Caddo were cautious, but not overly concerned about the Apache; 2) that the Apache were only one of several groups with hostile relations with the Caddo, but that this hostility did not prevent the Caddo from regularly hunting and trading across central and southern Texas before and after they had the horse; 3 ) that the East Texas forest never imposed a barrier to horse travel; and, 4) that while the Apache certainly were actively hostile to eastern groups, their push to the east was largely forced upon them by the arrival of the Comanche in the Southern Plains, interrupting the ApacheSpanish commerce in New Mexico in the early eighteenth century (Kavanagh 1986:60-64; John and Wheat 1989:76; John and Wheat 1991:157, 170). Each of these points is discussed below.

The documentary evidence indicates that the Caddo were not overly concerned about the Apache as a hostile force. We believe that this lack of fear relates to their own fighting abilities, their acquisition of the horse, and their large population base. When the French first encountered the Caddo, they noted that the Caddo raided to the west (across the Trinity and Brazos rivers), often returning with Apache captives whom they subsequently tortured to death (Margry n.d., roll 3:363). A few years later, the Spanish priests Espinosa (Swanton 1942:294) and Casañas (Swanton 1942:251) wrote that the Caddo undertook war parties to the west to seek out their enemies. Although each of these authors acknowledged the enmity between the Caddo and the Apache, none described large numbers of casualties on either side resulting from the hostilities, and none indicated that the Apache were the "major concern" for the Caddo that Hickerson (1995:7) has portrayed.

Hickerson (1995:8) believes that horses were important in the Apache's success against the Caddo. However, this position fails to acknowledge that, by the late seventeenth century, the Caddo themselves acquired horses in quantities that facilitated their ability to procure bison hides and meat, that were a boon in their trade with the French and Spanish, and that granted success in their raids of enemies. By the late seventeenth century, most Hasinai families had three or more horses (Margry n.d., roll 3:298, $325,333)$. Throughout the eighteenth century, Gregory (1973:292) has further 
documented that the Caddo continued to supply horses and hides (deer and bison) in large numbers to the Europeans (see also Perttula 1994). In 1744, more than 100,000 hides passed through Louisiana, many through the French post at Natchitoches (Gregory 1973:239). The Caddo obtained some horses by raiding Apache camps (Margry n.d., roll 3:325); others were acquired through trade with Native American groups other than the Apache (Smith 1995:16), particularly the Jumano and Wichita groups. In short, another look at the documentary record clarifies that the presence of the Apache to the west was insufficient for cessation of Caddo travel to the west, south, and northwest, areas that Hickerson (1995) considered to be the strongholds of the Apaches, to obtain the hides that they traded to the French in Natchitoches.

The Caddos' confidence appears to have been partly based on their population. Seventeenth century descriptions of the Caddo by both the Spanish (AGN 1684; Posadas 1982:36; Paredes 1968:467; Massanet 1957; Casañas [Swanton 1942]) and by other Native Americans (e.g., AGN 1683, $1684)$ indicate that they were a large, populous nation living securely in their homeland. Fray Nicolas Lopez (AGN 1684) wrote of the "vast and powerful kingdom of the Tejas (Caddo)" when he met their ambassadors in west-central Texas. Several months earlier, a Jumano Indian in El Paso stated (AGN 1683) that the Tejas often visited each other's settlements and were a large, powerful, and populous nation. This general impression of the Caddo held, and in 1686 , Paredes (1962:467) wrote in his overview that the explorations of Martin and Castillo in 1650 had not penetrated the lands of the Caddo "because it was recognized as being expansive and filled with many people". This impression is supported by Joutel's statement in 1687 on Caddoan fighting policy:

For that is their way of making war, in Turkish fashion, giving no quarter; they bring back these scalps as trophies, so that the huts of the warriors and brave men are known by the number of scalps in them (Margry n.d., roll 3: 340 ).

The impression, then, is one of a large, confident Indian nation that neither feared, nor underestimated, their western enemies, and that was known to initiate attacks on their own accord (Margry n.d., roll 3:284).

The documents also illustrate that the Caddo had other enemies. In 1691, Casañas (Swanton 1942:251) wrote that their enemies included "Apaches, Caaucozi, and Mani." Espinosa (Swanton 1942:286) added the Yojuanes to this list, and Joutel wrote in 1687 that the Choumanos (Jumanos), friends of the Cenis (Hasinai), often joined the Hasinai in attacks on the Ayano or Canohatino. The Caddo also had long-standing hostilities with the Osage, Choctaws, and Chickasaws (Smith 1995:14). Smith 
(1995:15) further points out that while "the Apaches quickly earned the enmity of all the Indians of Texas by stealing from the other, more established tribes", it was the Osage who "struck terror in the hearts of the Caddos" (Smith $1995: 14)$. In sum, the documents do not substantiate Hickerson's contention that the Apache represented the most feared, or even the only, enemy of the Caddo.

We also take exception to Hickerson's $(1995: 12)$ statements that the dense forests of eastern Texas served as protection against savage Apaches because they represented a barrier to travel. As noted by Joutel (Margry n.d. roll 3:290), Casañas (Swanton 1942), and all subsequent observers, the Caddo had their own horses which, as Smith has noted (1995:14), thrived and multiplied in the eastern Texas environment. The ability of horses to negotiate and maneuver in this setting is further underscored by the quantity of horses brought by Moscoso, De Leon, Terán, and others to the region in Spanish exploration and colonizing efforts. To be sure, as Hickerson (1995) notes, difficulties were encountered in these expeditions. However, the diaries indicate that the difficulties centered upon the problems attendant in crossing large, flooded rivers, and that flooded rivers were common not only in eastern Texas but also central and southern Texas. Terán (AGI 1692; Foster 1995:69) had to wait 12 days to cross the Trinity, and, on the same return to Mexico, was forced to wait at the Rio Grande because of floods. Governor Gregorio de Salinas Varona, traveling in 1693, was also forced to deal with swollen rivers (Foster et al. 1993), as were other expedition leaders. In other words, the rivers were temporary barriers to travel, but the forests were not.

It is unreasonable for Hickerson (1995:9) to characterize the Hasinai territory as remote. Existing aboriginal trade routes, trails, and later Spanish trails across Texas all led to the Hasinai, in particular to the Nabedache Caddo on San Pedro Creek, and then on across the Neches River. Not coincidentally, this location is also marked by the earliest, largest, and probably most important prehistoric Caddo mound center south of the Sabine River, the George C. Davis site (Story 1990:325, 340-341). The Caddo construction and use of this mound from as early as A.D. $800 / 900$ indicates that this part of the upper Neches River had been an significant population center long before the protohistoric era as Hickerson suggests.

Finally, we argue that the reason for Apache aggression against the Caddo and a number of other Southern Plains groups did not stem from their acquisition of the horse and Spanish weapons. Rather, their aggression stemmed from the inexorable push of the Comanche into the Southern and rolling Plains. Summaries of the shifts in Comanche and Apachean territories can be found in Kessell (1979), John (1975), John and Wheat (1989), and Kavanagh 
(1986). These researchers point out that once the Spanish recognized the prominence of the Comanche newcomers, they found it expedient to negotiate trading pacts with the Comanche and abandon a century of Apache alliances (John and Wheat 1989; Jackson 1995:226-227). Left at the mercy of the Spanish and the Comanches, the Apaches moved south and east. By 1700, they were in La Junta de los Rios, Nueva Vizcaya, Coahuila, and, occasionally, central Texas (Kenmotsu 1994:270), locations well to the south and east of their earlier range. Four years later, groups of Apaches pleaded for peace in El Paso following retaliatory raids by Spanish forces (AHP 1704; NMA 1710). In 1712, they were introduced to Ramirez in La Junta, and they indicated that they sought amicable relations with both the Spanish and the resident native groups (AGI 1716). Other reports of their requests for peace and/or alliances with native groups along the Rio Grande in Texas (Salinas 1990), and with Spanish military commanders in Mexico, are relatively common in the Parral archives. Those pleas for peace were a dramatic reversal of the regular and consistent small raids that they had previously undertaken against the natives in those regions.

As Kessell (1979), Kavanagh (1986), and John and Wheat (1989) have demonstrated, the reversal can be attributed to their replacement by the Comanches at the nexus of the Plains/Spanish relations and trade networks, and to the Comanches' military dominance of the Southern Plains within a few decades of their arrival in the early eighteenth century. Throughout the eighteenth century, the Comanches pushed the Apaches into regions, such as the fringes of eastern Texas, where their presence had been merely sporadic. The Apache themselves became "refugees driven...by the even more formidable Comanches" (Adams 1991:211). Indeed, the Comanche and Apache were implacable enemies, as Cortes indicated in his 1799 report:

The most irreconcilable hatred that the Apaches hold, and the war that they carry on most tenaciously, are against the Cumanche Indians. This hatred is as old as the nations themselves, and the war is waged with utmost vigor by the groups nearest to them, that is, the Faraones, Mescaleros, Llaneros, and Lipanes. There is no other apparent origin than that both the Cumanches and the aforementioned nations seek to have certain exclusive rights to the buffalo which abound to an astonishing degree on the lands of both sides (John and Wheat 1989:76).

As the Apache moved east and south out of the eastern Apacheria, conflicts with native inhabitants resulted. In La Junta and other southern regions, the Apaches sought to resolve the conflicts 
through peace. The Coahuiltecan groups, however, were displaced by the Apache after 1680 as the latter moved across the Edwards Plateau in search of sources of horses (Campbell 1983:345). On the eastern margins of the Blackland Prairie, however, the Apache either could not, or were not able to, find resolution through peace. Instead, they raided the Caddo and were, in turn, raided by the Caddo.

\section{Populations and Demography}

Hickerson (1995:6-7) argues that the Caddoan area, the Hasinai and Cypress Creek basin areas included, was more dispersely settled and less densely populated than Mississippian settlements in the Southeast, thus less susceptible to the spread of epidemic diseases. This runs counter to much recent archeological work on Mississippian communities, where there is actually little uniformity but much diversity among these polities in the character of settlement systems and settlement amalgamations, as well as in relative population densities (Rogers 1995:2325). Thus, Caddo settlements and population densities in East Texas were likely comparable to Mississippian groups in much of the interior Southeast.
It is interesting that Hickerson (1995:7) asserts that the Hasinai area was lightly settled. When the DeSoto-Moscoso entrada came through the Caddo province of Guasco ("an island of relative plenty" in the upper Neches/Angelina river basin according to Hudson [1996]), the Spanish were provisioned three times in a single year, a considerable achievement for a "lightly settled" province. Furthermore, the Cypress Creek basin was not sparsely populated; rather, it was perhaps the most densely populated region of northeastern Texas until at least the early $1600 \mathrm{~s}$, as large settlements and community cemeteries abound along Big and Little Cypress creeks and tributaries.

\section{Caddo Archeology in the Neches/Angelina River Basin}

Although this is not the place for a detailed review of the archeology of the upper Neches and Angelina river basins, the ancestral homeland of the Hasinai Caddo groups, the most current consideration of prehistoric and early historic sociopolitical organization provides no support for Hickerson's (1995:12) argument that the formation of a Hasinai confederacy was strongly influenced by the migration of Caddo groups from north and west (apparently the Nasoni and the Nadaco, according to Hickerson). Rather, the archeological record of the Anderson Cluster (the Frankston and Allen phases) indicates that: 
[t]he Allen Phase [ca. A.D. 16001750] is believed to have developed out of the Frankston Phase [ca. A.D. 1400-1600] and, more importantly, to have shared the same form of organization, kinds of intergroup interaction, and settlement patterns. In sum ... Late Caddoan groups in the upper Neches and Angelina drainages were socio-politically united, and this unity prevailed with only minor changes from perhaps A.D. 1400 into early historic times (Story and Creel 1982:34).

The archeological evidence summarized by Story and Creel (1982) does not suggest that the historic Allen phase is the product of the incorporation of Caddo groups from north of the Sabine River, or for that matter from any other part of the eastern Texas region. In fact, the distribution of known Allen phase archeological components (Story 1990: Figure 56) encompasses a larger area than that recognized by the Spanish for the different Hasinai groups.

If Caddoan groups from the Cypress Creek and Sulphur River basins moved into the Hasinai Caddo region beginning in the mid-seventeenth century, as Hickerson (1995:10) asserts, then we may posit that there should be some indication of a sharing of ceramic styles and technology between the post- 1650 Hasinai components (the Allen phase) and the antecedent Nasoni and Nadaco groups north of the Sabine River. In general, this part of eastern Texas was occupied by Titus phase groups after $c a$. A.D. 1450 (Thurmond 1985; Perttula 1995:Figure 10), and distinctive Titus phase engraved ceramic styles and vessel forms are well known. If we examine the ceramic assemblage from the early eighteenth century Deshazo site, the best known historic Caddo site in the upper Neches/Angelina river basin, it is readily apparent that Titus phase ceramics (Perttula 1995:Figures 11 and 18) are not present and, in fact as Fields (1995:228) notes, "there are no apparent nonlocal ceramics in the Deshazo collection". As with other Allen phase assemblages throughout eastern Texas, the Deshazo ceramics are dominated by Patton Engraved bowls (Story 1995:242). Ripley Engraved, the most recognizable Titus phase ceramic style, is absent, as are engraved bottle forms (Perttula 1995:Figure 11d-e, h), another distinctive vessel form that is common in Titus phase assemblages. From this evidence, there appears to have been little sharing of ideas or interaction between the Hasinai Caddo households at Deshazo and any Cypress Creek Caddo groups. 


\section{Conclusions}

In sum, Hickerson (1995:20) is correct in stating that "identification of the historical processes taking place in the material and social environment are important to any understanding of the influence on sociocultural change". However, by focusing on Apache aggression, Hickerson's article does not serve to better identify those processes that shaped Caddo lifeways after European contact, nor does it accurately reflect current archeological and documentary literature on the Apache or the Caddo, perhaps because it largely relies on only a few Spanish documents out of the hundreds available that are relevant.

Hickerson's statements that the Apaches had a reputation as fearsome and hostile warriors "that stayed with them through the 18 th century" is misleading. It is fair to characterize the Apache in the eighteenth century as a series of bands that were to be approached with caution and not to be ignored. Moreover, they were more actively fighting with eastern groups, including the Caddo and the Wichita groups, during the early to mideighteenth century (BA 1719). Significantly, this was the time that the thriving traffic in Apachean slaves began to develop between the Wichita, Hasinai Caddo, Comanche, and the French and Spanish markets at Natchitoches and Los Adaes, respectively, fueled principally by Wichita and Comanche raiding for horses among the Apache (Gregory 1973:261268, 287). Thus, to depict the Apache as fierce and successful warriors throughout the eighteenth century, killing hordes and forcing Caddoan coalescence in the Neches and Angelina river basins, fails to recognize the lack of archeological evidence of either Apache aggression or Caddoan coalescence in those river basins, but moreover also ignores the documentary evidence that strongly supports the notion that the Caddo were recognized by other Native American groups as a powerful nation that could, and did, undertake their own punitive expeditions against their enemies.

\section{References Cited}

Adams, D. B.

1991 Embattled Borderlands: Northern Nuevo Leon and the Indios Barbaros, 1686-1870. Southwestern Historical Quarterly 95(2):205220.
AGI (Archivo General de Indias)

1692 Diario y Derroteo por General Don Domino Terán. Audencia de Guadalajara, 66-6-18. 
1716 Cartta y Informe por el Capellan Fray Andres Ramires. Audiencia de Mexico, 61-6-7.

AGN (Archivo General de la Nacion)

1683 Provincias Internas 37. Expediente 4. Diario y Derroteo de Juan Dominguez de Mendoza, Cavo y Caudillo de este Pice de Hexercito que ba caminando al Descubrimiento del Horiente y Reino de los Texas a Pedimento de Don Juan Sabeata, Indio de Nacion Jumana con los Demas Capitanes de dicha Nacion.

1684 Provincias Internas 37. Expediente 4. Autos sobre la Ayuda al Paso del Norte por Capitan del Presidio, Juan Roque de Madrid.

HP (Archivo del Hidalgo de Parral)

1704 Autos Practicados con Motivo de la Guerra que Hacen los Enemigos de la real Corona. Microfilm on file, Nettie Lee Benson Latin American Library, University of Texas at Austin, frames 171-216.

BA (Bexar Archives)

1719 Carta al Rey por Rebolledo. Microfilm on file, The Center for American History, The University of Texas at Austin, Roll 8, frames 17-20.

Black, S. L., L. W. Ellis, D. G. Creel, and G. T. Goode

1996 Hot Rock Cooking on the Greater Edwards Plateau: Four Burned
Rock Midden Sites in West Central Texas. Studies in Archeology, Texas Archeological Research Laboratory, The University of Texas at Austin, in press.

Boyd, D., J. Peck, S. A. Tomka, and K. W. Kibler

1994 Data Recovery at Justiceburg Reservoir (Lake Alan Henry), Garza and Kent Counties, Texas: Phase III, Season 2. Report of Investigations 88. Prewitt and Associates, Inc., Austin.

Campbell, T. N.

1983 Coahuiltecans and Their Neighbors. In A. Ortiz (editor), Handbook of North American Indians, Volume 10: Southwest, pp. 343358. Smithsonian Institution Press, Washington, D.C.

Chafe, W.

1990 Caddo Names in the de Soto Documents. Paper presented at the de Soto Symposium, sponsored by the National Endowment for the Humanities and the University of Arkansas, Fayetteville.

Cole, N. M.

1975 Early Historic Caddoan Mortuary Practices in the Upper Neches Drainage, East Texas. Unpublished Master's thesis, Department of Anthropology, The University of Texas at Austin. 
Fields, R. C.

1995 Analysis of Native-Made Ceramics. In D. A. Story (editor), The Deshazo Site, Nacogdoches County, Texas, Volume 2: Artifacts of Native Manufacture, pp. 173-232. Studies in Archeology 21, Texas Archeological Research Laboratory, The University of Texas at Austin.

Foster, W. C.

1995 Spanish Expeditions into Texas, 1689-1768. University of Texas Press, Austin.

Foster, W. C. and J. Jackson (editors), and N. F. Brierley (translator)

1993 The 1693 Expedition of Governor Salinas Varona to Sustain the Missionaries among the Tejas Indians. Southwestern Historical Quarterly 97:264-311.

Gilmore, K

1986 French-Indian Interaction at an Early Eighteenth Century Post: the Roseborough Lake Site, Bowie County, Texas. Contributions in Archaeology 3, Institute of Applied Science, North Texas State University, Denton.

Gilmore, K. and O. McCormick

1980 Red River Archaeological Project, Phase I. Institute of Applied Science, North Texas State University, Denton.
1982 Red River Archaeological Project, Phase II. Institute of Applied Science, North Texas State University, Denton.

Gregory, H. F.

1973 Eighteenth Century Caddoan Archaeology: A Study in Models and Interpretation. Unpublished $\mathrm{Ph} . \mathrm{D}$. dissertation, Department of Anthropology, Southern Methodist University, Dallas.

Habicht-Mauche, J. A.

1987 Southwestern Style Culinary Ceramics on the Southern Plains: A Case Study of Technological Innovation and Cross-Cultural Interaction. Plains Anthropologist 32 (116): 175-189.

Hackett, C. W. (editor and translator) 1931-1946 Pichardo's Treatise on the Limits of Louisiana and Texas, 4 volumes. The University of Texas Press, Austin.

Hickerson, D.

1995 Historical Processes and the Political Organization of the Hasinai Caddo Indians. Caddo Archeology Newsletter 6 (3):5-15.

Hudson, C.

1996 Knights of Spain, Warriors of the Sun. University of Georgia Press, Athens, in press. 
Jackson, J. (editor)

1995 Imaginary Kingdom: Texas as Seen by the Rivera and Rubi Military Expeditions, 1727 and 1767. Texas State Historical Association, Austin.

John, E. A. H.

1975 Storms Brewed in Other Men's Worlds: The Confrontation of Indians, Spanish, and French in the Southwest, 1540-1795. Texas A\&M University Press, College Station.

John, E. A. H. (editor) and J. Wheat

(translator)

1989 Views from the Apache Frontier: Report on the Northern Provinces of New Spain by José Cortes, Lieutenant in the Royal Corps of Engineers, 1799. University of Oklahoma Press, Norman.

1991 Views from a Desk in Chihuahua: Manuel Merino's Report on Apaches and Neighboring Nations, ca. 1804. Southwestern Historical Quarterly 95 (2): 139-175.

Johnson, E. and V. T. Holliday

1995 Archeology and Late Quaternary Environments of the Southern High Plains. Bulletin of the Texas Archeological Society 66:519540.

Jones, B. C.

1968 The Kinsloe Focus: A Study of
Seven Historic Caddoan Sites in Northeast Texas. Unpublished Master's thesis, Department of Anthropology, University of Oklahoma, Norman.

Kavanagh, T. W.

1986 Political Power and Political Organization: Comanche Politics, 1786-1875. Unpublished Ph.D. dissertation, Department of Anthropology, University of New Mexico, Albuquerque.

Kenmotsu, N. A.

1992 The Mayhew Site: A Possible Hasinai Farmstead, Nacogdoches County, Texas. Bulletin of the Texas Archeological Society 63:135-174.

1994 Helping Each Other Out, A Study of the Mutualistic Relations of Small Scale Foragers and Cultivators in La Junta de los Rios Region, Texas and Mexico. Unpublished Ph.D. dissertation, Department of Anthropology, The University of Texas at Austin.

Kessell, J. L.

1979 Kiva, Cross, and Crown, The Pecos Indians and New Mexico 1540-1840. University of New Mexico Press, Albuquerque.

Margry, P. (editor)

n.d. Découvertes et établissements des Francais dans l'ouest et dans le sud de l'Amérique Septentrionale 
(1614-1754). 6 vols. English translation in Burton Historical Collection, Detroit Public Library, Detroit, Michigan.

Massanet, Fray D.

1957 Parecer del Padre Comisario Fray Damian Massanet y demas Religiosos Misioneros, Julio 19 de 1691 años. Boletin del Archivo General de la Nacion 28:346381. Mexico, D.F.

Meredith, H. L.

1995 Dancing on Common Ground: Tribal Cultures and Alliances on the Southern Plains. University Press of Kansas, Lawrence.

NMA (New Mexico Archives)

1710 Autos de Guerra y Diligencias que a Hecho el Governador General Don Antonio Balverde y Cossio para El Paso. Microfilm on file, Nettie Lee Benson Latin American Library, The University of Texas at Austin, roll 4, frames 228-243.

Paredes, Fray A. de

1968 Utiles y Curiosas Noticias del Nuevo Mundo Cibola y Otras Naciones Confidantes: la Antiqua Tradicion de Copala, Cuna, no Solo las Naciones Indianas. In Documentos para Servir a la Historia del Nuevo Mexico 15381778, pp. 460-482. Colecion Chimalistac, Educacion Jose Porrua Turanzas, Madrid.
Perttula, T. K.

1992 "The Caddo Nation:" Archaeological and Ethnohistoric Perspectives. University of Texas Press, Austin.

1993 Effects of European Contact on Native and Immigrant Indians in Northeast Texas. In N. A. Kenmotsu and T. K. Perttula (editors), Archeology in the Eastern Planning Region, Texas: A Planning Document, pp. 147-187. Cultural Resource Management Report 3. Department of Antiquities Protection, Texas Historical Commission, Austin.

1994 French and Spanish Colonial Trade Policies and the Fur Trade among the Caddoan Indians of the Trans-Mississippi South. In J. S. H. Brown, W. J. Eccles, and D. P. Heldman (editors), The Fur Trade Revisited: Selected Papers of the Sixth North American Fur Trade Conference, Mackinac Island, Michigan, 1991, pp. 7191. Michigan State University Press, East Lansing.

1995 The Archeology of the Pineywoods and Post Oak Savanna of Northeast Texas. Bulletin of the Texas Archeological Society 66:331-359.

Perttula, T. K, J. E. Bruseth, N. A. Kenmotsu, and W. A. Martin 1995 Archeological Testing at the 
Cabe Mounds (41BW14), Bowie County, Texas. Cultural Resource Management Report 8, Department of Antiquities Protection, Texas Historical Commission, Austin.

Posada, A. de

1982 Alonso de Posada Report 1686: a Description of the Area of the Present Southern United States in the late 17th Century, Vol. 4, edited and translated by $\mathbf{A}$. B. Thomas, Spanish Borderlands Series. Perdido Bay Press, Pensacola.

Rogers, J. D.

1995 The Archaeological Analysis of Domestic Organization. In J. D. Rogers and B. D. Smith (editors), Mississippian Communities and Households, pp. 7-31. University of Alabama Press, Tuscaloosa.

Salinas, M.

1990 Indians of the Rio Grande Delta, Their Role in the History of Southern Texas and Northeastern Mexico. University of Texas Press, Austin.

Smith, F. T.

1995 The Caddo Indians, Tribes at the Convergence of Empires, 15421854. Texas A\&M University Press, College Station.
Spielmann, Katherine, A.

1982 Inter-Societal Food Acquisition Among Egalitarian Societies: An Ecological Study of Plains/Pueblo Interaction in the American Southwest. Unpublished Ph.D. dissertation, Department of Anthropology, University of Michigan, Ann Arbor.

Story, D. A.

1990 Cultural History of the Native Americans. In D. A. Story, J. A. Guy, B. A. Burnett, M. D. Freeman, J. C. Rose, D. G. Steele, B. W. Olive, and K. J. Reinhard, The Archeology and Bioarcheology of the Gulf Coastal Plain, pp. 163-366. Research Series 38. Arkansas Archeological Survey, Fayetteville.

Story, D. A. (editor)

1982 The Deshazo Site, Nacogdoches County, Texas. Volume 1: The Site, Its Setting, Investigation, Cultural Features, Artifacts of Non-Native Manufacture, and Subsistence Remains. Texas Antiquities Permit Series 7. Texas Antiquities Committee, Austin.

1995 The Deshazo Site, Nacogdoches County, Texas. Volume 2: Artifacts of Native Manufacture. Studies in Archeology 21. Texas Archeological Research Laboratory, The University of Texas at Austin. 
Story, D. A. and D. G. Creel

1982 The Cultural Setting. In D. A. Story (editor), The Deshazo Site, Nacogdoches County, Texas, Volume 1: The Site, Its Setting, Investigation, Cultural Features, Artifacts of Non-Native Manufacture, and Subsistence Remains, pp. 20-34. Texas Antiquities Permit Series 7. Texas Antiquities Committee, Austin.

Swanton, J. R.

1942 Source Material on the History and Ethnology of the Caddo Indians. Bulletin 132. Bureau of American Ethnology, Smithsonian Institution, Washington, D.C.

Thurmond, J. P.

1985 Late Caddoan Social Group Identifications and Sociopolitical Organization in the upper Cypress Basin and its vicinity, Northeastern Texas. Bulletin of the Texas Archeological Society 54:185-200. 